\title{
Role of Nongovernment Organisations in the Development of the Kosovar Society
}

\author{
Hamdi Hoti*1, Demir LIMAJ ${ }^{2}$, Edisona KURHASKU- HOTI ${ }^{3}$
}

\begin{abstract}
Generally, the paper shows the importance that have non-government organization in Kosovo on development routes toward democratic and transparent society. Today, the main purpose of NGO's is creating a better life for society by researching for the needs of society and fulfilling these requirements in the near future. Today, in day life we are facing with different individual and groups of society and is being questioned about the purpose of the works of these organizations. Research results of the paper shows that NGO's have played and are playing positive important role in Kosovar society development, in generally developing in /special fields. Among the main requirements include cooperation and coordination between NGO's to achieve powerful impact in society development and increasing transparency for the public and creating reliability that it will not misused taken fonds and have the main mission improvement of society instead of benefits.
\end{abstract}

Keywords: NGO, cooperation, society, development, impact.

\section{Non-government organizations in Kosovar society}

Today, non-governmental organizations are considered important factors in creating a better life for individuals and for certain groups of different individuals, as well as for society, depending on the problem they address and try to solve.

According to the law, "Non-Governmental Organization (NGO)" is an independent non-profit legal entity, established for the realization of legitimate purposes for public benefit or mutual interest (KCSF, Law no. 06 / L-043 on freedom of association in nongovernmental organizations,, 2016-17). The Non-Governmental Organization (NGO) of a foreign or international country is a non-profit legal entity established outside the Republic of Kosovo (KCSF, Law no. 06 / L-043 on freedom of association in nongovernmental organizations, 2016-17). Also, the role of non-governmental organizations in the Kosovar society is important, as these organizations attract the attention of the public and the competent authorities for more careful treatment of the daily problems of citizens.

Most non-governmental organizations operating in Kosovo are local but there are also international ones. Civil society represents different groups of actors, communities and social formations, officially or not registered, representing a variety of roles and commitments in public life to protect and promote common values and objectives (Georgia Holmer et al., August 2018). The purpose of NGOs is to create a more environmentally friendly environment for society in general and for communities in

\footnotetext{
| ${ }^{*}$ Assoc. Prof. Dr. in Faculty of Economic at University "Ukshin HOTI" Prizren, Republic of Kosovo.

${ }^{2}$ Assist. Prof. Dr. in Faculty of Economic at University "Ukshin HOTI" Prizren, Republic of Kosovo.

${ }^{3}$ Master of Science on Economic field.
} 
particular where the realization of their goals should always bring results at the end of their activities.

Throughout the transition in Kosovo, the strengthening of NGOs (civil society) and the expansion of their influence in policy making has been one of the main goals of the commitment of the international factor. Because this is one of the main goals in any internationally sponsored democracy building agenda in any country in transition. Reasoning for this lies in the belief that a vibrant and representative society represents one of the last factors in the consolidation of democracy. Although this is an accurate and proven notion, the development of such a sensitive society cannot be done hastily and independently of other social and political conditions. Instead, efforts to enable a strong civil society in the post-conflict transition should be comprehensive in terms of its adjustment to the demands of time and social / institutional development (Institute, 2007).

Although we have a lot of information about NGOs that carry out activities in the country for areas and problems that NGOs raise for society, there is still a lack of information about the role they play in general and how they affect the parties of interest for whom they carry out the relevant activities, the groups with which they cooperate for the realization of these activities and the impact on third parties who are not involved in these activities.

\section{The role of civil society and parties of interest in the country}

Civil society is one of the main pillars of construction and operation of democratic society. Civil society organizations offer citizens an alternative way of advancing their common interests, determining the different views and securing their interests in decision-making processes or even benefiting from different services (Kosovo O. o.-R., 2013).

Civil society, by definition, encompasses a wide range of citizens' associations and organizations which operate in various social sectors with the exception of power and without its control. Among the classic members of civil society here are citizens 'associations (known to us as NGOs NGOs), or NGOs, trade unions, employers' associations, associations of various professions, as well as various informal groups of organized people about a common issue, problem or common interest. From a general point of view, civic organizations represent different identities, interests, problems and perspectives (Spasenoski, 2018). Due to this diversity and representativeness they absorb their necessary power and credibility for the role of catalyst of social processes and key players in the process of creating and changing certain policies and practices that affect or are in the interest of citizens.

In this process of participation, civic organizations, such as leaders and their representatives, must be independent in their actions even when in the realization of personal goals they must have direct cooperation with the authorities of different levels (Spasenoski, 2018).

Although traces of the actions of civil society in Kosovo have existed for many decades, in its modern sense the first initiatives and organizations of civil society in Kosovo date from the late 80 s and early 90s, after the fall of communism in Central and Eastern 
Europe and the beginning of a new form of political oppression and parallel life in Kosovo.

These organizations were mainly humanitarian in nature (providing humanitarian aid, protection of human rights, various civil movements, etc.), which in time took the form of a comprehensive peaceful resistance to the structures of that time (Kosovo O. o.-R., 2013).

Therefore, citizens join organizations in order to achieve their objectives and activities, as well as to protect the rights, interests and beliefs of their target groups, in accordance with legal norms, organizations can present and promote their attitudes and opinions for issues that are in their interest, to take initiatives and participate in the creation of public opinion and the creation of policies (Spasenoski, 2018).

\section{NGO's on Kosovo}

Defining civil society embodies the goal of representing the interests of citizens, whether they are a defined and well-defined group or even the interests that are considered the general good of society (KFOS, 2015). Civil society in Kosovo consists not only of registered NGOs, but also of other types of organizations, which can operate without the need to register with the relevant state authorities. That is why in Kosovo, civil society has always served as one of the essential pillars in efforts to build a healthy democracy. The nature of this civil society has been widely debated, but one of the main components in the last two decades established by law and in practice have been nongovernmental organizations (NGOs). As part of the constitutional right to freedom of association, each individual enjoys the right to form a collective with other individuals and to lay the foundations of an organization with the mission to serve the community from which it benefits. Society in general. (Lumezi, 2020), Kosovo is one of the countries that has received international financial assistance from international organizations and institutions. In addition to direct assistance provided to institutions for infrastructure, capacity building with staff and technical assistance, some of these funds have also gone to civil society organizations. Therefore, some NGOs have also benefited from donors and other public funds.

\section{Legislative framework of NGOs in Kosovo}

Democratic tradition and practice stipulate that citizens' rights to participate in the formulation of public policies must be enshrined in the constitution and further extended and clarified through special laws (Institute, 2007). Most non-governmental organizations register to gain the status of legal entity and the formal accompanying benefits that come from being a legal entity, such as the possibility of opening a bank account, applying and receiving donations from donors, etc. In Kosovo, NGOs can be registered in two forms, as an association or as a foundation. The association is an organization based on membership and can be established by at least three people, while the foundation is an organization based on capital and can be established by one person or through a will (KCS, 2018). Like all other entities, civil society organizations must act in accordance with the legal order and legal framework applicable in the country in 
which they operate, as well as with the principles of international law (KFOS, 2015). Freedom of association is a constitutional right, guaranteed by Article 44 of the Constitution (Kosovo P. o., 2008) of the Republic of Kosovo. This article guarantees the right of everyone to establish an organization without having to obtain a permit, to be or not to be a member of an organization, and to participate in the activities of an organization. The legal framework for freedom of association includes the current Law no. 04 / L-57 of the Freedom of Association in the NGO and the Administrative Instruction of the NRC - no. 02/2014 (MIAPA, 2020).

The legal forms for which freedom of association applies are: associations and foundations regulated by the law on freedom of association. It also includes trade unions, political parties, employers' associations, religious communities, etc., which are regulated by relevant laws. However, there are no legal provisions for the establishment of non-profit companies or for donations, although the latter is expressly not prohibited. The registration of NGOs is not mandatory, it is free of charge and the registration rules are simple, while the response from the Department for the registration of NGOs must be given within 60 days. The legal framework does not recognize the category of community-based organizations. However, since the exercise of freedom of association without the need to register is a constitutional right, defined by primary and secondary legislation, anyone can establish an organization, including a community-based one. Although there are no reports of any restrictions on the functioning of unregistered organizations, most local and international donors (including state institutions) do not provide funding for unregistered organizations. In January 2017, the Ministry of Public Administration launched the Electronic Registration System for NGOs, which facilitates the registration process of an NGO (online registration of NGO's, see https://ojq.rksgov.net/Login2.aspx). The system provides all the same services as the NGO Registration Department itself. The legislation also provides for the right to appeal, which is regulated by an administrative instruction.

However, the appeal process is considered to be problematic as the same authority has the mandate to establish a Complaints Commission. Also, networks are considered as associations and the same rules apply (KCSF, Law framework, 2020). The legal framework prohibits public authorities from interfering in the work and activities of NGOs, other than Article 18 of Administrative Instruction No. 02/2014 on the Registration and Functioning of NGOs. This article enables the Department for NGOs to suspend the activities of the NGO on the basis of a written request and the justification of the authorized security institution. The maximum duration of the suspension is one year, while the reasoning can be based on cases when the activity of the NGO is suspected to be inconsistent with the legal and constitutional order of the Republic of Kosovo and with international law. Civil society has argued that this article is not in line with primary legislation and international standards. However, this article remains in force and allows for unjustified state intervention in the leadership and activities of the CSOs.

On the other hand, there are no specific legal provisions that oblige the state to provide protection from third party interference (KCSF, Law framework, 2020). The CSOs in Kosovo seek and secure funding from various local and foreign sources in order to support their activities. However, the requirement for prior authorization of funds 
provided for in the Law on Prevention of Money Laundering and Terrorist Financing continues to be a serious procedure in the search and provision of financial resources. Finally, the legal provisions under the Law on Association Freedom in NGOs regarding the dissolution of NGOs are considered to be in line with international principles and standards (KCSF, Law framework, 2020). At the international level, there are several documents that define the main principles of the functioning of the civil sector, starting with the Universal Declaration of Human Rights, the International Convention on Civil and Political Rights, the European Convention on Human Rights, the CM/ Rec Recommendation (2007) 14 of the Committee of Ministers of the Council of Europe on Member States on the legal status of non-governmental organizations in Europe, etc. National legislation should be in line with the principles of these documents, while Kosovo has included in the legal framework most of the main principles around this sector (KFOS, 2015).

\section{Response of survey for Non-Government Organization}

In the surveys, questions were submitted, which are in closed form regarding the role and development of non-governmental organizations in the Republic of Kosovo. As a result of this work is the extraction of the real situation and the operation of these organizations which are in large numbers registered in the country. So the survey is divided into two parts, the demographic part and the research part about the topic made. Also, a total of 102 respondents who are part of non-governmental organizations as leaders, members and activists engaged for certain periods of time according to the activity of the organizations responded to this survey. Question A: In this part, the demographic situation presented according to the accepted surveys and the condition of the respondents is presented. So $52 \%$ of respondents are male and $48 \%$ are female, which shows that in non-governmental organizations there are a satisfactory number of females and not only males.

Gender?

102 responses

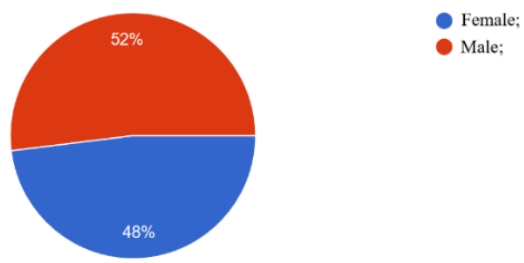

Figure 1: Gender of surveys respondents.

In this part is presented Gender as a result extracted from SPSS were frequency of Male respondents is 53 and for Female is 49.

Table 1: Gender.

Gender?

\begin{tabular}{lllll} 
& Frequency & Percent & Valid Percent & Cumulative Percent \\
\hline Valid $\quad$ Male & 53 & 52.0 & 52.0 & 52.0 \\
\hline
\end{tabular}




\begin{tabular}{ll|l|l|l} 
Female & 49 & 48.0 & 48.0 & 100.0 \\
\hline Total & 102 & 100.0 & 100.0 & \\
\hline
\end{tabular}

Question B: According of 102 respondets in below answer we have 39.1\% from the age of 18-30 years old which are members or activist of different nongovernment organization that operate on Kosovo and $32.4 \%$ are $31-34$ years old, than, $14.7 \%$ are from $45-55$ years old and ober 45 years old are just $13.7 \%$

\section{Age?}

102 responses
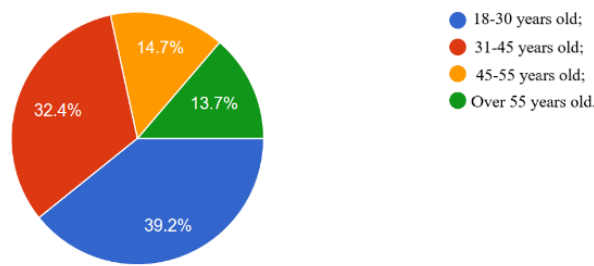

Figure 2: Age of responders. Source: Author (2020)

Table 2: Age.

Age?

\begin{tabular}{lllllll} 
& & Frequency & Percent & Valid Percent & Cumulative Percent \\
\hline Valid & $18-30$ & 40 & 39.2 & 39.2 & 39.2 \\
\cline { 2 - 6 } & $31-45$ & 33 & 32.4 & 32.4 & 71.6 \\
\cline { 2 - 6 } & $45-55$ & 15 & 14.7 & 14.7 & 86.3 \\
\cline { 2 - 6 } & Over 55 & 14 & 13.7 & 13.7 & 100.0 \\
\cline { 2 - 6 } & Total & 102 & 100.0 & 100.0 & \\
\hline
\end{tabular}

Question C: Whereas, from next question are attempted to derive level of education of respondets we have divide into 5 level which are generated and are shown results in following part of text. According of answers we have $44.1 \%$ that have master degree or are in process and in the same time they are part of NGOs, $30.4 \%$ are part of Bachelor level degree or continue education in this level, than with $9.8 \%$ we have with secondary school level of respondents and 9.8 doctor of science and a part of them are $\mathrm{PhD}$ candidates.

\section{Educational level?}

102 responses

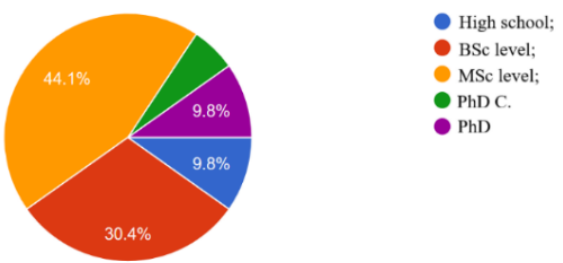

Figure 3: Education level of respondents. Source: Author (2020)

The higher frequency of respondents is for MSc level with 45 than BSc with 31 where higher cumulative percent is for $\mathrm{PhD}$ level with $100 \%$. 
Table 3: Education level.

Education level?

\begin{tabular}{|c|c|c|c|c|c|}
\hline & & Frequency & Percent & Valid Percent & $\begin{array}{l}\text { Cumulative } \\
\text { Percent }\end{array}$ \\
\hline \multirow[t]{6}{*}{$\overline{\text { Valid }}$} & Primary school & 10 & 9.8 & 9.8 & 9.8 \\
\hline & BSc Level & 31 & 30.4 & 30.4 & 40.2 \\
\hline & MSc Level & 45 & 44.1 & 44.1 & 84.3 \\
\hline & PhDc Level & 6 & 5.9 & 5.9 & 90.2 \\
\hline & PhD Level & 10 & 9.8 & 9.8 & 100.0 \\
\hline & Total & 102 & 100.0 & 100.0 & \\
\hline
\end{tabular}

The following questions and answers are the research part extracted according to the organization of this survey.

This part of analyzing is done on SPSS software.

Table 4: Establishment of NGO's

Question 1. Year of establishment of NGO's operate in Kosovo.

\begin{tabular}{lllllll} 
& & Frequency & Percent & Valid Percent & Cumulative Percent \\
\hline Valid & $2015-2016$ & 47 & 46.1 & 46.5 & 46.5 \\
\cline { 2 - 6 } & $2017-2018$ & 35 & 34.3 & 34.7 & 81.2 \\
\cline { 2 - 6 } & 2019-2020 & 19 & 18.6 & 18.8 & 100.0 \\
\cline { 2 - 6 } & Total & 101 & 99.0 & 100.0 & \\
\hline Missing & System & 1 & 1.0 & & \\
\hline Total & 102 & 100.0 & & \\
\hline
\end{tabular}

Table 5: Impact of NGO's in society.

Question 2: What kind of impact do you have as NGO's in society?

\begin{tabular}{lllllll} 
& & Frequency & Percent & Valid Percent & $\begin{array}{l}\text { Cumulative } \\
\text { Percent }\end{array}$ \\
\hline \multirow{2}{*}{ Valid } & Positive & 92 & 90.2 & 90.2 & 90.2 \\
\cline { 2 - 6 } & We don't have impact & 10 & 9.8 & 9.8 & 100.0 \\
\cline { 2 - 6 } & Total & 102 & 100.0 & 100.0 & \\
\hline
\end{tabular}

TTable 6: Importance of NGO's in economic development.

Question 3: Do you think that NGO's generally have important role in economic development of Kosovar society?

\begin{tabular}{|c|c|c|c|c|c|}
\hline & & Frequency & Percent & Valid Percent & $\begin{array}{l}\text { Cumulative } \\
\text { Percent }\end{array}$ \\
\hline \multirow[t]{3}{*}{$\overline{\text { Valid }}$} & Yes & 68 & 66.7 & 67.3 & 67.3 \\
\hline & Maybe & 33 & 32.4 & 32.7 & 100.0 \\
\hline & Total & 101 & 99.0 & 100.0 & \\
\hline Missing & System & 1 & 1.0 & & \\
\hline Total & & 102 & 100.0 & & \\
\hline
\end{tabular}


Table 7: Level activity.

Question 4: Level activity of NGO's?

\begin{tabular}{|c|c|c|c|c|c|}
\hline & & Frequency & Percent & Valid Percent & $\begin{array}{l}\text { Cumulative } \\
\text { Percent }\end{array}$ \\
\hline \multirow[t]{5}{*}{$\overline{\text { Valid }}$} & Local & 21 & 20.6 & 20.8 & 20.8 \\
\hline & Regional (inside of state) & 42 & 41.2 & 41.6 & 62.4 \\
\hline & National & 23 & 22.5 & 22.8 & 85.1 \\
\hline & International & 15 & 14.7 & 14.9 & 100.0 \\
\hline & Total & 101 & 99.0 & 100.0 & \\
\hline Missing & System & 1 & 1.0 & & \\
\hline Total & & 102 & 100.0 & & \\
\hline
\end{tabular}

Table 8: Organization legality.

Question 5: Is your organization officially (legal) registered?

\begin{tabular}{llll|ll} 
& & Frequency & Percent & Valid Percent & $\begin{array}{l}\text { Cumulative } \\
\text { Percent }\end{array}$ \\
\hline \multirow{2}{*}{ Valid } & Registered & 90 & 88.2 & 89.1 & 89.1 \\
\cline { 2 - 6 } & Not registered & 11 & 10.8 & 10.9 & 100.0 \\
\cline { 2 - 6 } & Total & 101 & 99.0 & 100.0 & \\
\hline Missing & System & 1 & 1.0 & & \\
\hline Total & 102 & 100.0 & & \\
\hline
\end{tabular}

Table 9: NGO's registering.

Question 6: If your NGO's is legal registered, what kind of register it has?

\begin{tabular}{lllllll} 
& & Frequency & Percent & Valid Percent & Cumulative Percent \\
\hline Valid & Center & 28 & 27.5 & 29.2 & 29.2 \\
\cline { 2 - 6 } & Foundation & 27 & 26.5 & 28.1 & 57.3 \\
\cline { 2 - 6 } & Association & 38 & 37.3 & 39.6 & 96.9 \\
\cline { 2 - 6 } & Other & 3 & 2.9 & 3.1 & 100.0 \\
\cline { 2 - 6 } & Total & 96 & 94.1 & 100.0 & \\
\hline Missing & System & 6 & 5.9 & & \\
\hline Total & 102 & 100.0 & & \\
\hline
\end{tabular}

Table 10: Main cases of active organization.

Question 7: Which are main cases that your organization is active?

\begin{tabular}{|c|c|c|c|c|c|}
\hline & & Frequency & Percent & Valid Percent & Cumulative Percent \\
\hline \multirow[t]{9}{*}{$\overline{\text { Valid }}$} & Politics & 8 & 7.8 & 7.9 & 7.9 \\
\hline & Educational & 36 & 35.3 & 35.6 & 43.6 \\
\hline & Socio-Economics & 23 & 22.5 & 22.8 & 66.3 \\
\hline & Human rights & 11 & 10.8 & 10.9 & 77.2 \\
\hline & Agriculture & 8 & 7.8 & 7.9 & 85.1 \\
\hline & Certification & 7 & 6.9 & 6.9 & 92.1 \\
\hline & Climate change & 5 & 4.9 & 5.0 & 97.0 \\
\hline & $\begin{array}{l}\text { Energy/ } \\
\text { energy }\end{array}$ & & 2.9 & 3.0 & 100.0 \\
\hline & Total & 101 & 99.0 & 100.0 & \\
\hline
\end{tabular}




\begin{tabular}{lll|l|l|l}
\hline Missing & System & 1 & 1.0 & \\
\hline Total & 102 & 100.0 & \\
\hline
\end{tabular}

Table 11: Participants of NGO's in society.

Question 8: Would greater and more active participants help civil society in policy making of substantial society and wider?

\begin{tabular}{lllllll} 
& & Frequency & Percent & Valid Percent & Cumulative Percent \\
\hline Valid & Yes & 87 & 85.3 & 86.1 & 86.1 \\
\cline { 2 - 6 } & No & 3 & 2.9 & 3.0 & 89.1 \\
\cline { 2 - 6 } & I don't know & 11 & 10.8 & 10.9 & 100.0 \\
\cline { 2 - 6 } & Total & 101 & 99.0 & 100.0 & \\
\hline Missing & System & 1 & 1.0 & & \\
\hline Total & & 102 & 100.0 & &
\end{tabular}

Table 12: Cooperation between NGO's.

9: Does it have cooperation between NGO's in Republic of Kosovo?

\begin{tabular}{lllllll} 
& & Frequency & Percent & Valid Percent & Cumulative Percent \\
\hline \multirow{7}{*}{ Valid } & Yes & 31 & 30.4 & 31.0 & 31.0 \\
\cline { 2 - 6 } & Partial cooperation & 61 & 59.8 & 61.0 & 92.0 \\
\cline { 2 - 6 } & No & 8 & 7.8 & 8.0 & 100.0 \\
\cline { 2 - 6 } & Total & 100 & 98.0 & 100.0 & \\
\hline Missing & System & 2 & 2.0 & & \\
\hline Total & $\mathrm{q} 102$ & 100.0 & & \\
\hline
\end{tabular}

Table 13: Descriptive statistics of survey.

Descriptive Statistics

\begin{tabular}{|c|c|c|c|c|c|}
\hline & $\mathrm{N}$ & Minimum & nMaximum & nMean & $\begin{array}{l}\text { Std. } \\
\text { Deviation }\end{array}$ \\
\hline Gender? & 102 & 1 & 2 & 1.48 & .502 \\
\hline Age? & 102 & 1 & 4 & 2.03 & 1.048 \\
\hline Education level? & 102 & 2 & 6 & 3.75 & 1.048 \\
\hline $\begin{array}{l}\text { 1. Year of establishment of NGO's1 } \\
\text { operate in Kosovo? }\end{array}$ & 101 & 1 & 3 & 1.72 & .763 \\
\hline $\begin{array}{l}\text { 2. What kind of impact do you1 } \\
\text { think you have as NGO's in } \\
\text { society? }\end{array}$ & 102 & 1 & 3 & 1.20 & .598 \\
\hline $\begin{array}{l}\text { 3. Do you think that NGO's1 } \\
\text { generally have important role in } \\
\text { economic development of } \\
\text { Kosovar society? }\end{array}$ & & 1 & 3 & 1.65 & .943 \\
\hline 4. Level Activity of NGO's? & 101 & 1 & 4 & 2.32 & .969 \\
\hline $\begin{array}{l}\text { 5. Is you organization officially1 } \\
\text { (legal) registered? }\end{array}$ & 101 & 1 & 2 & 1.11 & .313 \\
\hline $\begin{array}{l}\text { 6. If your NGO's is legal9 } \\
\text { registered, what kind of register it } \\
\text { has? }\end{array}$ & & 1 & 4 & 2.17 & .890 \\
\hline
\end{tabular}




\begin{tabular}{l|l|l|l|l}
\hline $\begin{array}{l}\text { 8. Which are main cases that your101 } \\
\text { organization is active? }\end{array}$ & 1 & 8 & 3.31 & 1.787 \\
$\begin{array}{l}\text { 9. Would greater and more active101 } \\
\text { participants help civil society in } \\
\text { policy making of substantial } \\
\text { society and wider? }\end{array}$ & 1 & 3 & 1.25 & .639 \\
$\begin{array}{l}\text { 10. Does it have cooperation100 } \\
\text { between NGO's in Republic of } \\
\text { Kosovo? }\end{array}$ & 1 & 3 & 1.77 & .584 \\
\hline \begin{tabular}{l} 
Valid N (list wise) \\
\hline
\end{tabular} & & & & \\
\hline
\end{tabular}

Chi-Square Results

Table 14: Crosstabulation of question 4 and 3 and their relationship results.

4. Your level activity as NGO's? * 3. Do you think that NGO's generally have important role in economic development of Kosovar society?

\section{Crosstabulation}

Count

3. Do you think that NGO's generally have important role in economic development of Kosovar society?

\begin{tabular}{|c|c|c|c|c|}
\hline & & Yes & Maybe & Total \\
\hline \multirow{4}{*}{$\begin{array}{l}\text { 4. Your } \\
\text { activity } \\
\text { NGO's? }\end{array}$} & levelLocal & 15 & 6 & 21 \\
\hline & $\begin{array}{l}\text { asRegional (Inside of } 2 \\
\text { state) }\end{array}$ & 27 & 14 & 41 \\
\hline & National & 12 & 11 & 23 \\
\hline & International & 14 & 1 & 15 \\
\hline Total & & 68 & 32 & 100 \\
\hline
\end{tabular}

Table 14.1: Results of question fourth and third with Chi-Square Tests.

\section{Chi-Square Tests}

\begin{tabular}{llll} 
& Value & df & Asymptotic Significance (2-sided) \\
\hline Pearson Chi-Square & $7.272^{\mathrm{a}}$ & 3 & .064 \\
\hline Likelihood Ratio & 8.413 & 3 & .038 \\
\hline Linear-by-Linear Association & .509 & 1 & .475 \\
\hline N of Valid Cases & 100 & &
\end{tabular}

a. 1 cells $(12.5 \%)$ have expected count less than 5 . The minimum expected count is 4.80 .

Comment: It has not significant relationship between activity level of NGO's and the role plays in economic development of Kosovar society.

Table 15: Crosstabulation of question sixth and fourth.

1. Which are main cases that you organization is active? $* 4$. Your level activity as NGO's?

\section{Crosstabulation}

Count

4. Your level activity as NGO's Total 


\begin{tabular}{|c|c|c|c|c|c|c|}
\hline & & Local & $\begin{array}{l}\text { Regional } \\
\text { (inside } \\
\text { state) }\end{array}$ & $\mathrm{N}$ & 1 Int & \\
\hline \multirow{8}{*}{$\begin{array}{l}\text { 8. Which are } \\
\text { cases that } \\
\text { organization } \\
\text { active? }\end{array}$} & mainPolitics & 3 & 1 & 4 & 0 & 8 \\
\hline & youEducational & 4 & 19 & 7 & 6 & 36 \\
\hline & is Socio-Economics & 5 & 10 & 3 & 5 & 23 \\
\hline & Human rights & 4 & 5 & 1 & 1 & 11 \\
\hline & Agriculture & 3 & 3 & 2 & 0 & 8 \\
\hline & Certification & 1 & 1 & 5 & 0 & 7 \\
\hline & Climate changes & 1 & 1 & 1 & 2 & 5 \\
\hline & $\begin{array}{l}\text { Energy/ Nuclea } \\
\text { energy }\end{array}$ & & 2 & 0 & 1 & 3 \\
\hline Total & & 21 & 42 & 23 & 15 & 101 \\
\hline
\end{tabular}

Table 15.1: Results of question sixth and fourth with Chi-Square Tests.

\section{Chi-Square Tests}

\begin{tabular}{llll} 
& Value & df & Asymptotic Significance (2-sided) \\
\hline Pearson Chi-Square & $30.833^{\mathrm{a}}$ & 21 & .076 \\
\hline Likelihood Ratio & 32.492 & 21 & .052 \\
\hline Linear-by-Linear Association & .223 & 1 & .637 \\
\hline N of Valid Cases & 101 & & \\
\hline
\end{tabular}

a. 26 cells $(81.3 \%)$ have expected count less than 5 . The minimum expected count is .45 .

Comment: It has not significant relationship between activities as NGO's and main cases on that NGO's are active.

Table 16: Crosstabulation of question sixth and fourth.

2. Which are main cases that your organization is active? * 3 . Do you think that NGO's generally play important role in economic development in Kosovar society?

\section{Crosstabulation}

\section{Count}

3. Do you think that NGO's generally plays important role in economic development in Kosovar society?

\begin{tabular}{|c|c|c|c|c|}
\hline & & Yes & Maybe & Total \\
\hline \multirow{2}{*}{\multicolumn{2}{|c|}{$\begin{array}{l}\text { 8. Which are mainPolitics } \\
\text { cases that yourEducational }\end{array}$}} & 7 & 1 & 8 \\
\hline & & 30 & 6 & 36 \\
\hline \multirow{6}{*}{ organization is active $\mathrm{S}$} & Socio-Economics & 16 & 7 & 23 \\
\hline & Human rights & 7 & 4 & 11 \\
\hline & Agriculture & 6 & 2 & 8 \\
\hline & Certification & 0 & 7 & 7 \\
\hline & Climate changes & 1 & 4 & 5 \\
\hline & $\begin{array}{l}\text { Energy / Nuclear } \\
\text { energy }\end{array}$ & & 1 & 2 \\
\hline Total & & 68 & 32 & 100 \\
\hline
\end{tabular}


Table 16.1: Results of question seventh and third with Chi-Square Tests.

Chi-Square Tests

\begin{tabular}{llll} 
& Value & Df & Asymptotic Significance (2-sided) \\
\hline Pearson Chi-Square & $26.057^{\mathrm{a}}$ & 7 & .000 \\
\hline Likelihood Ratio & 27.443 & 7 & .000 \\
\hline Linear-by-Linear Association & 17.363 & 1 & .000 \\
\hline N of Valid Cases & 100 & & \\
\hline
\end{tabular}

a. 9 cells $(56.3 \%)$ have expected count less than 5 . The minimum expected count is .64 .

Comment: According results, Test Chi-Square is significant and shown that it has relationship between main cases were NGO's are active and their role in economic development of Kosovo, however, analyze condition it's not completed (9 cells (56.3)) expecting counting less than 5 . This value should be at least under $20 \%$.

Table 17: Crosstabulation of question fourth and nineth.

4. Your level activity of NGO's? * 9. Does it have enough cooperation between NGO's in Kosovo? Crosstabulation

Count

10. Does it has enough cooperation between NGO's in Kosovo?

\begin{tabular}{|c|c|c|c|c|c|}
\hline & Yes & Partial cooperation & Jo & Total \\
\hline \multirow{4}{*}{$\begin{array}{l}\text { 4. Your } \\
\text { activity } \\
\text { NGO's? }\end{array}$} & levelLocal & 4 & 14 & 3 & 21 \\
\hline & $\begin{array}{l}\text { asRegional (Inside } \\
\text { state) }\end{array}$ & of7 & 33 & 1 & 41 \\
\hline & National & 11 & 9 & 3 & 23 \\
\hline & International & 9 & 5 & 1 & 15 \\
\hline Total & & 31 & 61 & 8 & 100 \\
\hline
\end{tabular}

Table 17.1: Results of question fourth and nineth with Chi-Square Tests.

\section{Chi-Square Tests}

\begin{tabular}{lllll} 
& Value & df & Asymptotic Significance (2-sided) \\
\hline Pearson Chi-Square & $19.438^{\mathrm{a}}$ & 6 & .003 \\
\hline Likelihood Ratio & 19.600 & 6 & .003 \\
\hline Linear-by-Linear Association & 7.662 & 1 & .006 \\
\hline N of Valid Cases & 100 & &
\end{tabular}

a. 5 cells $(41.7 \%)$ have expected count less than 5 . The minimum expected count is 1.20 .

Comment: It has significant relationship between activity level of NGO's and their cooperation. Chi-Square is significant, but test condition it's not completed. Except values in 5 cells it should be at least under $20 \%$.

Table 18: Crosstabulation of question third and nineth.

3. Do you think that NGO's generally plays important role in economic development of Kosovar society? * 9. Does it have enough cooperation between NGO's in Kosovo? Crosstabulation

Count 


\begin{tabular}{|c|c|c|c|c|}
\hline & $\begin{array}{l}10 . \\
\text { betw } \\
\text { Yes }\end{array}$ & $\begin{array}{l}\text { it have enou } \\
\text { GO's in Kosc } \\
\text { Partial } \\
\text { cooperation }\end{array}$ & Jo & Total \\
\hline 3. Do you think that NGO'sYes & 26 & 40 & 2 & 68 \\
\hline $\begin{array}{l}\text { generally plays important role in Maybe } \\
\text { economic development of } \\
\text { Kosovar society? }\end{array}$ & 5 & 20 & 6 & 31 \\
\hline Total & 31 & 60 & 8 & 99 \\
\hline
\end{tabular}

Table 18.1: Results of question third and nineth with Chi-Square Tests.

Chi-Square Tests

\begin{tabular}{llll} 
& Value & Df & Asymptotic Significance (2-sided) \\
\hline Pearson Chi-Square & $10.536^{\mathrm{a}}$ & 2 & .005 \\
\hline Likelihood Ratio & 10.303 & 2 & .006 \\
\hline Linear-by-Linear Association & 9.199 & 1 & .002 \\
\hline N of Valid Cases & 99 & & \\
\hline
\end{tabular}

a. 1 cells $(16.7 \%)$ have expected count less than 5 . The minimum expected count is 2.51 .

Comment: It has significant relationship between role of NGO's in economic development of Kosovar society and cooperation between NGO's. Analyze condition it's completed.

\section{Conclusions}

Non-governmental organizations nowadays are playing an important role in the social, economic and cultural development of society in general, through their positive impact in most cases, where the main responsibility for the general situation in the country is still left to the institutions of the public sector, where NGOs are increasingly strengthening their role in social, economic and cultural development in general, where civil society organizations are making great efforts to develop and democratize society by making a direct contribution to the areas mentioned above but also by engaging with different contributions to public institutions to be more accountable to the citizens of the country.

Therefore, the empowerment of civil society organizations and their role in society makes their commitment very useful not only to clarify the position of civil society organizations towards public sector institutions for accountability, but also to develop and improve the accountability of organizations themselves. Today, various trends are being observed in the country to address issues of accountability of NGOs, such as: cooperation and coordination between NGOs, increasing transparency in the financing of NGOs in order to create credibility that is not being done misuse of funds where the primary mission is to influence society instead of its own benefits, increase NGO activities in rural areas in order to be active in these areas of Kosovo, legal framework development, treatment governance and accountability, increasing the number of projects in the field of education, etc. Therefore, these years the development of the country has largely depended on local and international funds that have operated in 
Kosovo, as well as foreign donors who are still continuing to finance NGO's projects, creating new jobs and doing numerous investments for the needs of the Kosovar society.

\section{References}

Georgia Holmer et al. (August 2018). The Role of Civil Society in Preventing and Countering Violent Extremism and Radicalization that Lead to Terrorism. Vienna-Austri: OSCE Transnational Threats Department (TNTD) Action against Terrorism Unit (ATU).

Institute, K. R. (2007). Analytical Study at the End of the Second Mandate of the Assembly of Kosovo. Prishtine: C I V I L S O C I E T Y A N D T H E L E G I S L A T I V E P R O C E S S I N K O S O V O.

KCS. (2018). Kosovo Civil Society Index, Kosovo Civil Society Foundation. Prishtina: KCS.

KCSF. (2016-17). Law no. 06 / L-043 on freedom of association in non-governmental organizations,. Prishtine: KCSF.

KCSF. (2020, 04 22). Law framework. Retrieved from KCS Foundation: https://www.kcsfoundation.org/hulumtimi-avokimi/liria-e-asociimit/korniza-ligjore/

KFOS. (2015). WHO GUARDS THE GUARDIANS?, Prishtine: KFOS .

Kosovo, O. o.-R. (2013). GOV ERNMENT STRATEGY FOR COOPERATION WITH CIVIL SOCIETY 2013-2017. Prishtine: Government of Kosovo.

Kosovo, P. o. (2008). Constitution of the Republic of Kosovo. Prishtine: Parliament of Republic of Kosovo.

Lumezi, A. (2020, 04 23). N'thelb. Retrieved from Kosovo 2.0: https://kosovotwopointzero.com/arekosovos-ngos-under-threat/

MIAPA. (2020, 04 24). Online application for NGO. Retrieved from Ministry of Internal Affairs and Public Administration: https://map.rks-gov.net/page.aspx?id=2,35

Spasenoski, D. (2018). Advocacy for local civic organizations and journalists, The project is funded by the European Union 2018. European Union . 